This case was first seen by Mr. Inglis Pollock, to whom we are indebted for permission to publish the above report.

\title{
REFERENCES
}

1. Goldstein, I., and Wexler, D.-Arch. f. Ophthal., Vol. CIII, p. 552, 1930.

2. Axenfeld, Th., and Stock, W.-Klin. Monatsbl. f. Augenheilk., Vol. XLIX (i). p. 28, 1911.

3. Davis, A. E.-Trans. Amer. Ophthal. Soc., Vol. XVIII, p. 59, 1920.

4. Alexjewa, W. L.-Sammelschrift f. Augenheilk., Moskow, p. LXVI, 1921.

5. Suganuma, V.-Arch.f. Ophthal., Vol. CXVIII, p. 443, 1927.

6. Marchesani, O.-Bericht über Heidelberg Ophthal. Ges., p. 53, 1934.

7. Fleischer, B.-Iber. Ophthal., p. 560, 1914.

8. Axenfeld, Th.-Ber. $\ddot{i}$. deutsch Opthalm. Ges., Vol. XLII, p. 298, 1920.

9. Eppenstein. A.-Arch.f. Ophthal., Vol. CIII, p. 195, 1920.

10. Birnbaum, Prinzmetal and Connor.-Arch. Int. Med., Vol LIII. p. 410, 1934.

11. Marchesani, O.-Arch. f. Augenheilk., Vol. CIX, p. 124, 1935.

12. Gilbert, T. W.-Klin. Monatsbl. f. Augenheilk., Vol. XCIV, p. 335, 1935.

13. E. von Hippel.-Arch. f. Ophthal., Vol. CXXXIV, p. 121, 1935.

14. Bürger.-Med. rec., Vol. XCVII, p. 431, (March 13, 1920).

15. Letulle.-Presse Med., Vol. XXXVI, p. 193, (February 15, 1928).

16. Sigler.-Am. Clin. Med., Vol. III, p. 475, (January, 1925).

17. Mayerhofer, H.-Wien. Klin. Wochenschr., Vol. XL, p. 1199, 1927.

18. Lluesma, P.-Med. ibera, p. 537, 1929.

19. Kokott, W.-Klin. Monatsbl.f. Augenheilk., Vol. XCIV, p. 327, 1935.

20. Cords.-Zeitschr. f. Augenheilk., Vol. XXVI, p. 441, 1911 .

21. Igersheimer, J.-Arch. f. Ophthal., Vol. LXXXII (ii), p. 215, 1912.

22. Nicolate.-Boll. d'ocul., VI, Nr. 10, p. 735, 1927.

23. Natale, A.-Rev. Assoc. med. Argent., Vol. XLVI, p. 1055, 1932.

24. Gilbert, W.-Mïnch. Med. Wochenschr., Vol. LXI, No. 6, p. 306, 1914.

25. Löwenstein, A.-Med. Klin., p. 879, 1931.

26. Santowsky, P.-Arch. oftal. Buenos Ayres, Vol. VIII, p. 44, 1933.

27. Anthonisen, H.-Acta Ophthal., Vol. XIII, p. 289, 1935.

28. Knapp, Paul.-Klin. Monatsbl.f. Augenheilk., Vol. XCIV, p. 748, 1935.

29. Eccheverria, M.-Zeitschr. f. Augenheilk., Vol. XLVIII, p. 203, 1922.

30. Ballantyne, A. J.-Ophthalmoscope, Vol. VII, p 662, 1909.

31. Marchesani, O., and Stauzi, R. H.-Arch. f. Augenheilk., Vol. CIX, p. 281, 1935.

32. Axenfeld, Th.-Klin. Monatsbl. f. Augenheilk, Vol. LXXXV, p. 478, 1930.

\section{KATHOLYSIS IN THE TREATMENT OF RETINAL DETACHMENT. A PRELIMINARY NOTE}

BY

\author{
H. B. Stallard
}

LONDON

EleCtrolysis was tried in the surgical treatment of retinal detachment towards the end of the 19 th century by Montgomery, Snell, Terson, Motais, Abadie, Schoellers, Albrand and others, and it has recently been revived by Imre and Vogt and others who have termed it katholysis. The main difference between this therapeutic procedure in those days and now is the importance of the accurate localization of retinal tears with the object of closing 
them through a circumvallation of choroido-retinal adhesions induced aseptically by chemical caustics or through the medium of such physical agents as heat and electricity.

The therapeutic principle of katholysis is to effect a caustic reaction through the liberation of sodium and hydroxyl ions at

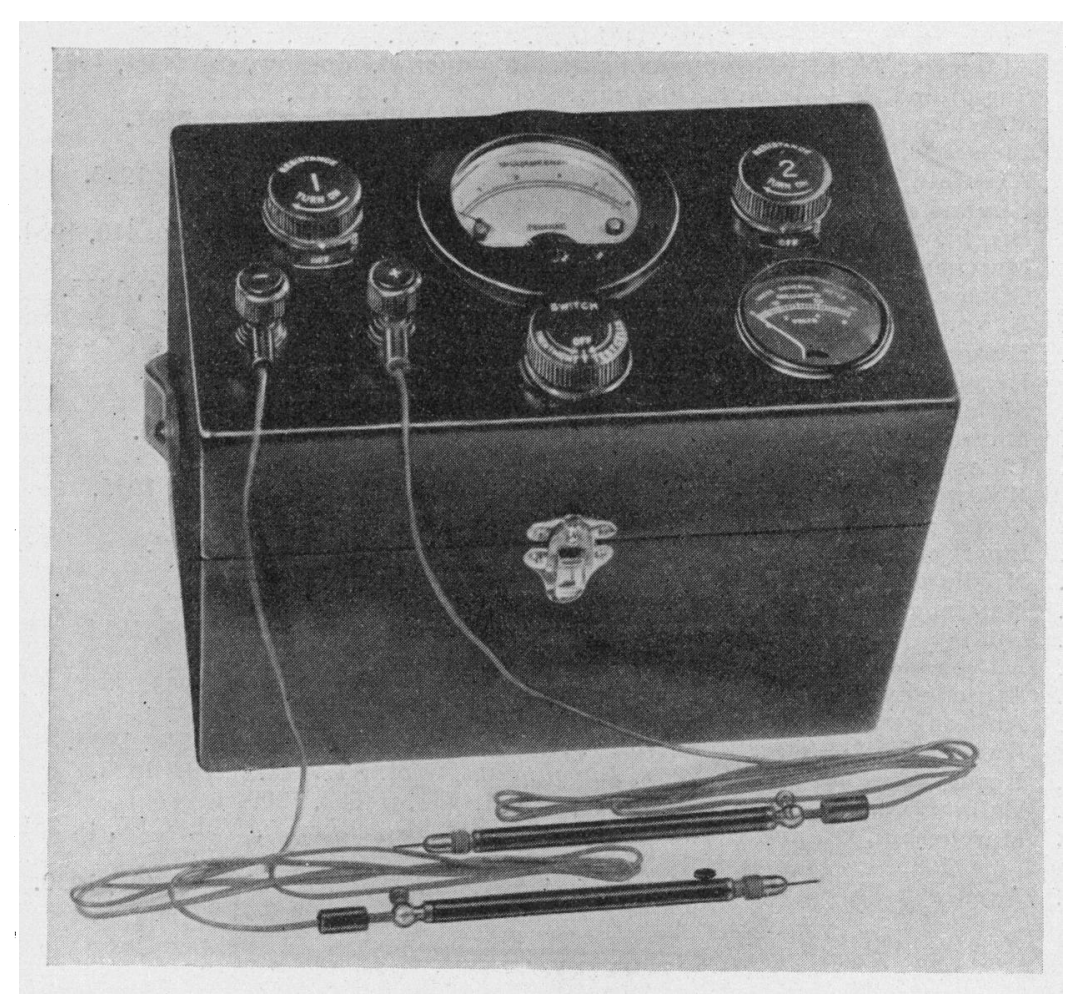

FIG. 1.

Hamblin's Ocular Ionizer.

the point of the negative terminal which is inserted through the sclera into the choroid.

The apparatus which I have used is called Hamblin's Ocular Ionizer and I am grateful to Mr. Smellie of Theodore Hamblin for the following notes about this instrument. (See fig. 1).

Hamblin's Ocular Ionizer employs a dry cell battery of considerable current capacity, with an electromotive force variable from 3 to 36 volts. The dry cell is eminently suitable for the purpose as it yieids a current entirely free from oscillations or ripples unless it is allowed to run down to a very low state. In the latter event; some slow fluctuations of electromotive force occur. 


\section{Katholysis in the Treatment of Retinal Detachment}

The negative connecting wire from the battery is joined in series to two finely wound resistances of 5,000 ohms and 25,000 ohms, one of which acts as a coarse and the other as a fine adjustment. From the resistances the connection passes to the milliamperemeter and thence to the negative pole of the battery. The switch has two alternative pairs of contacts, one pair merely connecting the two poles of the battery to the voltmeter for the purpose of testing the electromotive force of the cells. The other pair of terminals closes the circuit between the external terminals when the appropriate connections have been made by way of the applicators to the patient's tissues.

Caution suggests that while these connections are being made, both resistances should be at their maximum and the current correspondingly at minimum, as indicated by the word " off." The windings are so fine that the current increase can be controlled by steps of less than one tenth of a milliampère up to the required amount.

The apparatus is contained in a convenient carrying case and is complete with the necessary flexes, negative and positive needle holders, and straight and bent needles of platinum alloy.

The positive terminal is a zinc rod $1 \mathrm{~mm}$. in diameter held in a suitable holder which is attached by a rubber-coated cable to the appropriate battery terminal. As a convenient alternative to this, A. H. Briggs conceived the idea of attaching the positive wiring to an Arruga's retractor used during the operation to hold aside Tenon's capsule and the orbital tissues.

The negative terminal is a platinum-iridium needle coated with bakelite except at its extremities; one of which is blunt $0.75 \mathrm{~mm}$. in diameter and is inserted into a slot in the holder, the other is fined down to a needle point of 1 to 2 or more millimetres in length as is required. Straight needles are used for the preequatorial part of the globe and for the post-equatorial region a right-angled bend some $4 \mathrm{~mm}$. from its point facilitates the insertion of the needle. With this right-angled needle I have sometimes experienced a "give" in its shaft particularly when it has become slightly blunt and in operations in the macular area where the sclera is thicker than elsewhere. Probably a shorter shaft and a modified holder would prevent this " give." Needles of $1 \mathrm{~mm}$. long are I think sufficient when operating near the equator in a myope, $1.5 \mathrm{~mm}$. long for the ora serrata tears and 2 $\mathrm{mm}$. long for the posterior $1 / 3$ of the globe. In one case I had to pass the needle through the fibres of the inferior oblique muscle at its insertion and selected a $4 \mathrm{~mm}$. needle for this purpose. It worked admirably.

The technique is as follows. The pupil is dilated by a mydriatic and local anaesthesia is produced by 4-6 drops of pantocain 1 per 
cent. instilled at 5 minute intervals before operation. Pantocain does not dull the corneal epithelium as cocaine is apt to do. A clear cornea is essential for such ophthalmoscopic examinations as it is necessary to make during the operation.

Tenon's capsule is injected with 2 c.c. of 2 per cent. novocain and 2 drops of adrenalin $1 / 5000$ are instilled into the conjunctival sac. Dark green sterile towels are used to isolate the eye instead of white towels which reflect light and thereby minimise its concentration if an ophthalmoscopic examination is made by the indirect method during the operation. The lid speculum is of a dull black finish to avoid annoying reflexes from its surface.

I prefer to operate in gloves and I have never found that this has impaired my sense of touch when trephining the eye at the end of operation. The conjunctiva is incised at the appropriate site and 2 or 3 sutures are inserted in the posterior edge of this incision and clamped by forceps to the sterile lint mask surrounding the eye, thus retracting the conjunctiva and rendering it easily accessible for suturing at the end of operation.

Tenon's capsule is then incised and the sclera cleanly exposed by passing the closed blades of a pair of blunt-ended scissors into the incision and opening them out between the sclera and deep surface of Tenon's capsule. A traction suture of No. 1 silk may be inserted through the superficial half of the sclera at an appropriate site where maximum exposure of the sclera is desired. If it is necessary to divide an extra-ocular muscle two mattress sutures are inserted into the muscle belly $3 \mathrm{~mm}$. behind its insertion and the muscle is divided $2 \mathrm{~mm}$. in front of the sutures. Care is taken to avoid any surgical traumatism in the vicinity of the vortex veins.

Arruga's retractor (see fig 2 ) is an excellent mechanical aid in the exposure of the sclera as far back as the dural sheath of the optic nerve. For rotating the globe forwards and to gain a better access to the posterior $1 / 3$ of the sclera, Down Bros. made for me a curved double pronged hook with teeth $0.6 \mathrm{~mm}$. long set obliquely at an angle of $60^{\circ}$ with the vertical for insertion into the sclera. This instrument grips the sclera very well without penetrating it, steadies the globe, and its handle does not obstruct the field of overation. (See fig. 3). It is unnecessary to use a traction suture when this instrument is employed.

The surgeon may elect to use both electrodes himself entrusting the traction on the globe and the retraction of soft tissue surrounding it to his assistant or he mav prefer to hold the traction suture with one hand and the negative electrode with the other, the assistant taking charge of the positive electrode. Briggs' modification of Arruga's retractor which is connected with the positive 
terminal saves an additional instrument and frees one hand of either the surgeon or his assistant.

If this retractor is not used the positive electrode is placed on the sclera $3 \mathrm{~mm}$. or so away from the needle of the negative electrode which is inserted through the sclera and into the choroid.

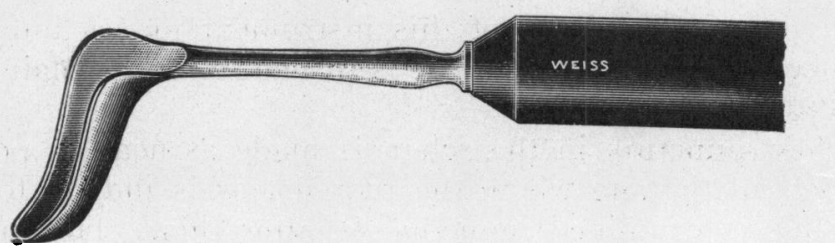

Fig. 2.

Arruga's Retractor.

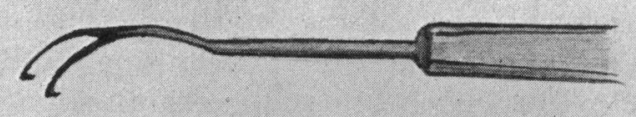

a.

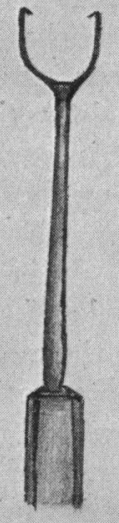

b.

Fig. 3.

A double pronged retractor. The radij of curvature of the long axis and the transverse axis of the prongs coincides approximately with that of the sclera in these two planes respectively. The sharp teeth at the extremity of the prongs.project backwards at an angle of $60^{\circ}$ and are $0.6 \mathrm{~mm}$. long. 
By pressing a button on the handle of the negative electrode the current passes between the two electrodes. Bubbles of hydrogen gas are liberated at the tip of the needle in the choroid. I have used a current of 1.75 milliampères, and more recently 3 milliampères, for 4 secs., respectively. The milliampèremeter readings show that the current is maintained at a constant level throughout the operation. The lever of this instrument moves immediately into place as soon as the current is turned on and remains at this point until it is cut off.

The first puncture in the sclera is made as near as possible 2 mms. behind the site where the retinal tear is judged to be and the fundus is examined immediately after this. The opthalmoscope may be held wrapped in a sterile towel and a sterile rubber finger stall slipped over the index finger in order to operate the milled disc which rotates the lenses. Bubbles of hydrogen gas are seen at the point of perforation of the electrode and these serve for intra-ocular localization of the relation of the puncture to the retinal tear. As the puncture hole is very small and is sometimes difficult to locate after ophthalmosçopic examination it is advisable to mark it first with a spot of sterile methyl gentian violet. On the Continent ophthalmoscopic examination is made by the indirect method. Large and moderate sized holes are visible by this means of examination but I have found it impossible to see small holes or splits except by direct ophthalmoscopy. For marking purposes scleral punctures are also made on the nasal and temporal sides of the tear and then anteriorly, the diamond shaped area so demarcated indicates the zone for intensive application of katholysis around and over the site of the retinal tear. The needle (negative pole) should be inserted at intervals of $0.5 \mathrm{~mm}$. over this area as the scars produced by this method of treatment are small and do not appear to be more than 0.5 or $0.75 \mathrm{~mm}$. in diameter on ophthalmoscopic examination. Where the retina is shallow and at the macular and posterior pole of the eye a greyish-white fluffy edged cloud is readily seen at the point of the needle in addition to the bubbles. (Vide infra). (Recently I have made in some cases a circumvallation of 2 or 3 rows of Larsson's surface diathermy, the points of contact being placed $3 \mathrm{~mm}$. apart, outside the area treated by katholysis. It is quite unnecessary and may be even mischievous to apply diathermy for more than 2 or at the most 3 rows $(6 \mathrm{~mm}$.) around the site of the retinal tear. Extensive plastering of the globe with diathermy may lead to an increase of the inter-retinal fluid by exudation from the choroid and owing to widespread damage to this structure interfere with its power to absorb any small residue of inter-retinal fluid that may exist after operation). !

The sclera is trephined over the site of the retinal tear except 
when this is at the ora serrata or when the retina lies adjacent to the choroid and the inter-retinal fluid has accumulated elsewhere in which case the most dependent part of the eye over the site of the detachment is selected, having due regard to the position in which the head will be placed after operation.

In order to avoid damage to the choroidal vessels, which if cut by the trephine may retract beneath the sclera and cause an extensive intra-ocular haemorrhage, the trephine incision should stop after dividing all but a thin expanse of the deepest layers of scleral fibres. These fibres are then carefully picked up by a fine curved hook with a $1.5 \mathrm{~mm}$. cutting edge on its concavity. A cruciform incision is made through the deepest layers of the sclera and through this opening the choroid herniates. There is seldom any choroidal bleeding when this technique is practised, but if it occurs it should be checked immediately by the application of a probe heated in a spirit flame. A choroidal haemorrhage results in a failure to establish union between the retina and the choroid around the tear.

The choroid is then split with a blunt punctum dilator and the inter-retinal fluid evacuated. Tenon's capsule is replaced over the sclera and the edges of the conjunctival wound brought together with a few interrupted sutures of fine silk. Atropine is instilled, sterile pads soaked in ol.parolein are applied to the eye and a many-tailed bandage (Foster Moore pattern) is applied firmly.

The head is placed so that as far as possible gravity will permit the vitreous to press the retina against the choroid at the site of the retinal tear and at the same time permit drainage through the trephine hole. There is no need to disturb the dressing for three days when the lid margins may be gently swabbed and some warmed atropine drops instilled into the lower fornix by gently drawing down the lower lid without the patient opening or moving his eyes.

The second dressing is done on the 6th day and then on alternate days until the 14th day when Lochbrille. glasses with a central aperture of $3 \mathrm{~mm}$. are substituted for the dressings.

I think it is undesirable to examine the fundus before the 8 th day when a brief survey with reduced ophthalmoscope illumination may be made. To place the uveal tract at rest atropine drops are instilled at each dressing and I think should be continued for at least two months after operation and even three months when a Larsson surface diathermy operation has been done on account of the risk of late iritis in the latter operation.

For at least three months after operation the patient should take great care to avoid stooping, lifting heavy weights and straining. Jolts and knocks about the head and face are alwavs dangerous
in such cases. 


\section{Commentary}

In favour of katholysis is the precision with which its effect on the ocular tissues is circumscribed. There is no extensive spread of the current and on this account no damage is inflicted on other intra-ocular structures remote from the area of operation. After katholysis I have not yet seen such complications as cyclitis, iritis, cataract and optic neuritis which follow in some cases in retinal detachment treated by any one of the surgical diathermy procedures.

Ophthalmoscopically the choroido-retinal scars appear to be 0.5 to $0.75 \mathrm{~mm}$. in diameter, are well localized and do not appear to cause extensive fibrosis of the choroid, a feature which when widespread must damage the choroid and interfere with the absorption of the inter-retinal fluid. In most cases of retinal detachment treated by katholysis there are a few fine opacities in the vitreous over the site of the operated area for three or four weeks but elsewhere this structure is very little disturbed.

The minute and well localized areas where the caustic effect of katholysis has operated are particularly advantageous in the treatment of a retinal tear at or near the macula where it is essential to avoid widespread damage to the adjacent retina and the optic nerve.

Another advantage of katholysis is its value in localizing the site of the retinal tear. At the point of insertion of the negative electrode through the sclera and choroid a string of hydrogen bubbles about $2-3 \mathrm{~mm}$. long is to be seen, easily recognizable on ophthalmoscope examination and these afford an important mark of the relationship of the puncture to the site of the retinal tear. In the katholysis operation when a retinal tear lies beneath the course of an extra-ocular muscle there is no need to divide it as a needle $4 \mathrm{mms}$. long may be used to pierce the muscle fibres and then the sclera and choroid. In one case under $\mathrm{mv}$ care at Moorfields the inferior oblique muscle was pierced in this manner at its insertion. Division of an extra-ocular muscle is, in some instances, necessary for the purpose of surgical access to postequatorial parts of the sclera but for the exposure of the sclera at and in front of the equator a muscle may be gently retracted by means of a double loop of No. 1 silk passed round its belly.

So far I have never seen intense reaction after katholvsis with choroidal hyperaemia and coniunctival chemosis as sometimes occurs after diathermy and renders the prognosis of some cases bad.

Also there are no dense adhesions formed between the sclera and Tenon's capsule, a feature which makes exposure of the sclera a relatively easy matter if a second operation should prove to be 
necessary. After surface diathermy the sclera and Tenon's capsule are so densely matted together that clear exposure and haemostasis are only effected after considerable trouble.

Some recent research work by Weekers on the surgical treatment of retinal detachment has shown the importance of the part played by plugs of organized granulation tissue which, passing through puncture wounds in the ocular tunics, adhere firmly to the episcleral tissues outside and to the vitreous within but not to the choroid and sclera on their way through these structures. The function of these granulation tissue plugs is to act as links between the outer surface of the vitreous and the episcleral tissues holding the retina pinned back in juxtaposition with the choroid.

Up to date insufficient histological examinations have been made after katholysis to ascertain whether this feature has any bearing on the success or failure of the katholysis operation when the negative needle has been deliberately passed into or just through the retina during operation.

Other lesser advantages are concerned with the apparatus which is simple in structure, reliable, sensitive, portable and inexpensive. Among the disadvantages may be mentioned the lowered intraocular pressure after several punctures have been made with the kathode needle and some inter-retinal fluid has been lost. However, this does not make trephining at the end of operation insuperably difficult for with patience and care it may be effected without any untoward accident. I think trephining is the most satisfactory method of draining the inter-retinal fluid. A trephine hole takes longer to close than the punctures with micro-pins and other such devices. Multiple fine punctures may all close simultaneously in a relatively short time whereas drainage from a trephine hole carefully placed and fashioned will be effective at least for several days after operation and in some cases for several weeks.

The tenacity of the choroido-retinal scar after katholysis is problematical. Up to date I have had the impression that the scars are too small and feeble to seal effectively a large retinal tear and some moderate sized holes in the upper half of the retina in the majority of such cases.

\section{Results}

As yet I have treated by katholysis alone too few cases to give any fair statistics of the results of treatment. My impression is that katholysis is of value in anterior dialysis in the lower half of the retina. The operative reaction is well localized and does not spread to the ciliary body and with the help of the vitreous and gravity the choroido-retinal adhesions seem to be firm enough to hold the retina in situ. Of three cases of oral tears in the lower 
half of the globe two have been operative successes and one, after an immediate success, recurred.

In two cases of moderate myopia the lower half of the retina was detached but no retinal hole was found. Katholysis was employed in an attempt to pin down the retina immediately behind the ora serrata and just in front of, and behind the equator by two lines of punctures in these respective planes passing between the lower borders of the internal and external recti muscles. In both cases there was immediate success but one recurred one month and the other two months after operation.

In the upper half of the globe the sealing of extensive rents and large horseshoe-shaped tears has not been effective. In a few cases the retina remained in situ during the patient's stay in hospital but recurred within a few days of discharge. Others were a failure from the outset. With the present technique I feel that katholysis alone is insufficient to effect firm and reliable union between the choroid and retina around large tears situated in the upper half of the globe and should be augmented by surgical diathermy.

Recently it has been my practice in such cases to make a number of punctures with the kathode over the site of the hole and to circumvallate its edges with two or three rows of punctures set 0.5 mms. apart and outside this to apply two or three rings of Larsson's surface diathermy the points of contact on the sclera being placed $2 \mathrm{mms}$. apart. (In three cases of large upper temporal horseshoe rents and two cases of multiple round holes treated by this modification the result has been successful up to date).

\section{Conclusion and Summary}

Katholysis in the surgical treatment of retinal detachment is of value for the purpose of localizing the site of a retinal hole in relation to the external surface of the sclera at the time of operation. The cauterization produced leads to fine choroido-retinal scars which in my opinion may be adequate for sealing small holes and for tears in the lower half of the retina but have insufficient tenacity for moderate and large holes in the upper half of the retina.

Up to date none of the serious immediate and late post-operative complications which are seen in some cases treated by surgical diathermy has been noted after katholysis.

\section{REFERENCES}

Arruga, H.-Detachment of the Retina. Barcelona, 1936.

Imre.-Zeitschr. $f$. Augenheilk., Vol. LXXXIV, p. 302, 1934.

Ibid., Vol. EXXXV; p. 336, 1935.

Cole Marshall, J.-Detachment of the Retina. London, 1936.

Montgomery,' W. T.-Jl. Amer. Med. Assoc., Vol. XXVII, p. 702, 1896.

Sne11, S.-Trans. Ophthal. Soc. U.K., Vol. XVI, p. 72, 1895-6. Vogt.-Klin. Monatsbl. f.Augenheilk., Vol. XCVI, p. 15, 1936; Brit. Jl. of

von Szily ánd Machemer.-Klin. Monatsbl. f. Augenheilk., Vol. XCVI, p. 36, 1936.

Weak Ibid., Vol. XCVI, p. 191, 1936

Weekers, L.-Arch. d'Ophtal., Vol. LII, p. 636, 1935. 